\title{
К ВОПРОСАМ ДИВЕРСИФИКАЦИИ ИМПОРТА ПРОДОВОЛЬСТВИЯ И РЕАЛИЗАЦИИ ПОЛИТИКИ ЕГО ИМПОРТОЗАМЕЩЕНИЯ В РОССИИ
}

\author{
(C) 2020 Солошенко Руслан Викторович \\ доктор экономических наук \\ Курская Государственная сельскохозяйственная академия имени И.И. Иванова, Россия, Курск \\ E-mail: soloshenko-v-m@yandex.ru
}

В статье рассматривается динамика и структура российского импорта продовольственных товаров и сельскохозяйственного сырья в разрезе стран дальнего зарубежья, Евросоюза и странпартнеров на постсоветском пространстве. В исследовании отмечается рост объема импорта продовольственных товаров и сельскохозяйственного сырья, в том числе из стран Евросоюза, что свидетельствует о низкой эффективности ответных мер России в виде продовольственного эмбарго в адрес стран, поддержавших антироссийские санкции.

Ключевые слова: санкции, продовольственное эмбарго, импортозамещение, АПК, сельское хозяйство, география импорта.

Обеспечение продовольственной безопасности является стратегической задачей государства. Не смотря на огромный природноресурсный потенциал, Россия долгие годы испытывала недостаток отечественного продовольствия на внутреннем рынке, и длительный период времени вынуждена была импортировать сельскохозяйственную продукцию, сырье и продовольствие для обеспечения потребностей внутреннего рынка и перерабатывающих отраслей [1]. После введения ограничительных мер против России со стороны западных стран вопросы импортозамещения стали основным экономическим ориентиром в санкционном противостоянии между Россией и странами, поддержавшими санкции. В 2014 г. в России было введено продовольственное эмбарго, запрещающее ввоз сельскохозяйственной продукции, сырья и продовольствия из стран Евросоюза, Норвегии, США, Канады и Австралии [2].

После ужесточения внешнеторговой политики возместить дефицит продовольствия на отечественном рынке за счет собственного производства в быстрые сроки оказалось невозможно, что по-новому поставило вопрос о государственной поддержке сельского хозяйства. Без нее российский АПК не может быть настолько же рентабельным, как, например, в западных странах, поскольку в рамках ВТО уровень поддержки в России оказался несопоставим с уровнем ЕС 4 млрд. долл. США против 108 млрд. долл. США, и уровнем Китая (147 млрд. долл. США) и США (24 млрд. долл. США), в то время как отечествен- ный АПК находится в менее привлекательных природно-климатических условиях [1, 3].

В условиях курса на импортозамещение, взятого в 2014 г., в отечественном АПК удалось добиться успехов в наращивании производства мяса свиней, птицы, сахара и зерна. Постепенно снижается степень технической зависимости от импортных поставок сельскохозяйственной техники из Беларуси, растет импорт сельскохозяйственной техники из стран дальнего зарубежья, а импортозамещение на рынке сельскохозяйственной техники за счет отечественных производителей при нынешнем состоянии сельскохозяйственного машиностроения в России весьма проблематично [5]. В то же время наблюдается медленный прирост производства молока и мяса крупного рогатого скота, где по-прежнему остаются нерешенными проблемы с финансированием из-за длительной окупаемости и низкой рентабельности производства. Также остается проблемным производство плодов и овощей [4].

Не смотря на запрет ввоза сельскохозяйственной продукции из стран Евросоюза, являвшегося и остающегося основным торговым партнером России по поставкам продовольствия, импорт продовольственных товаров был диверсифицирован в сторону стран дальнего зарубежья - Африки, Латинской Америки и Азии [6].

Исследуя динамику импорта продовольственных товаров и сельскохозяйственного сырья из стран дальнего зарубежья и Евросоюза, стоит обратиться к периоду 2015-2018 гг., отражающему пик экономического кризиса в Рос- 
сии 2015-2016 гг. и подъем, начавшийся в 2017 г. Динамику импорта за 10 месяцев 2019 г. стоит представить с целью отражения тенденций торговли в наиболее близкий по временным рамкам период к текущему времени.

По объемам импорта продовольственных товаров и сельскохозяйственного сырья абсолютным лидером является Евросоюз. На втором месте Китай, на третьем - Бразилия, хотя в 2015 г. Бразилия опережала Китай, на четвертом - Эквадор, на пятом - Турция, объемы поставок из которых ежегодно превышают миллиард долларов США. Основные импортеры продовольствия в России представлены в таблице 1 в зависимости от уровня относительного прироста в 2018 году относительно показателя 2015 года.

В динамике максимальный прирост в период 2015-2018 гг. показывает Иран, импорт из которого увеличился почти вдвое. На фоне диверсификации источников поставок тропических фруктов и овощей с целью круглогодичного обеспечения внутреннего рынка, существенно вырос импорт из Чили $(35,0 \%)$. Не смотря на введенное эмбарго, импорт продовольствия из Евросоюза вырос на 28,0\%, превосходя в динамики прироста даже Китай, показатель прироста которого составил 23,2\%. Диверсификация по- ставщиков продовольствия как таковая не произошла - например, не превысил 6\% прирост импорта из Аргентины, Марокко и Парагвая. Самое существенное сокращение импорта произошло в отношении Исландии $(-84,3 \%)$, поддержавшей антироссийские санкции, что существенно ударило по экспорту Исландии, где Россия в крупных объемах закупала рыбу и морепродукты. Почти наполовину сократился импорт из Бразилии, где в исследуемом периоде разразился внутренний экономический кризис, а колебание курса российской валюты только усугубило положение во внешней торговле между странами. Сократился в динамике и импорт продовольственных товаров из Турции (по отношению в 2015 г. в 2016 г. импорт снижался в 2,2 раза), на что влияние оказал внутренний кризис в Турции и обострение отношений между Россией и Турцией в 2015 г. после уничтожения турецким истребителем российского бомбардировщика в Сирии.

Таким образом, исходя из анализа динамики объемов импорта продовольственных товаров и сельскохозяйственного сырья из Евросоюза и стран дальнего зарубежья, стоит отметить, что пятерка наиболее значимых партнеров России по импорту не изменилась, а крупнейшим из

Таблица 1. Динамика импорта продовольственных товаров и сельскохозяйственного сырья из Евросоюза и стран дальнего зарубежья, млн. долл. США

\begin{tabular}{|l|c|c|c|c|c|c|}
\hline \multicolumn{1}{|c|}{ Страны } & 2015 г. & 2016 г. & 2017 г. & 2018 г. & $\begin{array}{c}2019 \text { г. } \\
\text { (январь- } \\
\text { октябрь) }\end{array}$ & $\begin{array}{c}\text { Изменение } \\
2018 \text { г. к } \\
2015 \text { г.,\% }\end{array}$ \\
\hline Иран & 204 & 233 & 273 & 395 & 310 & 93,6 \\
\hline Чили & 634 & 546 & 633 & 856 & 610 & 35,0 \\
\hline Страны ЕС & 5684 & 5632 & 6735 & 7276 & 5865 & 28,0 \\
\hline Китай & 1541 & 1621 & 1769 & 1899 & 1364 & 23,2 \\
\hline Фарерские острова & 277 & 280 & 370 & 336 & 229 & 21,3 \\
\hline Сербия & 311 & 343 & 404 & 373 & 318 & 19,9 \\
\hline ЮАР & 239 & 200 & 263 & 286 & 245 & 19,7 \\
\hline Египет & 361 & 288 & 403 & 421 & 348 & 16,6 \\
\hline Эквадор & 1145 & 1211 & 1299 & 1289 & 1050 & 12,6 \\
\hline Аргентина & 742 & 616 & 579 & 786 & 640 & 5,9 \\
\hline Марокко & 343 & 402 & 388 & 350 & 239 & 2,0 \\
\hline Парагвай & 857 & 697 & 625 & 871 & 542 & 1,6 \\
\hline Израиль & 307 & 268 & 297 & 275 & 193 & $-10,4$ \\
\hline Турция & 1380 & 625 & 1057 & 1133 & 943 & $-17,9$ \\
\hline Пакистан & 131 & 105 & 66,6 & 89 & 115 & $-32,0$ \\
\hline Бразилия & 2554 & 2189 & 2477 & 1355 & 1246 & $-46,9$ \\
\hline Исландия & 95 & 7 & 7 & 15 & 10,2 & $-84,3$ \\
\hline
\end{tabular}

Источник: рассчитано автором по данным Федеральной службы государственной статистики [7] 
них, несмотря на санкции, остается Евросоюз. Это, с одной стороны, говорит о неэффективности объявленного продуктового эмбарго, а с другой стороны, о проблемах диверсификации поставщиков для обеспечения потребностей населения. Сокращение импорта из Бразилии и Турции связано с их внутренними проблемами, а в отношении Турции большую роль сыграли российские санкции против Турции в ответ на ее действия в Сирии.

Отдельного внимания заслуживает оценка динамики импорта продовольственных товаров и сельскохозяйственного сырья из странпартнеров на постсоветском пространстве. Среди них стоит выделить Беларусь, Азербайджан и Украину. С Казахстаном у России тесные внешнеторговые связи, но импорт из Казахстана носит непродовольственный характер, оттуда преимущественно импортируются руды, шлаки, черные металлы, минеральное топливо, продукты неорганической химии и др. [8].

Наиболее крупным партнером России во внешней торговле на постсоветском пространстве является Беларусь, импорт из которой после введения антироссийских санкций устойчиво увеличивался, во многом благодаря использованию обходных барьеров российского эмбарго европейскими странами через территорию Беларуси (рисунок 1).

В динамике импорт из Беларуси вырос на $28,6 \%$, из Азербайджана - на 94,8\%, а импорт из Украины сократился на 59,5\%. Что касается соотношения, то Беларусь в 2015 г. импортировала в Россию в 11,7 раза больше, чем Азербайджан, и в 9,4 раза больше Украины. В 2018 г. разрыв с Азербайджаном сократился до 7,7 раза, а с Украиной возрос до 29,8 раза. Увеличение объемов внешней торговли, в частности импорта, в отношении Беларуси закономерно в условиях интеграции государств в рамках Евразийского экономического союза. Сокращение торговли с Украиной также логично и вытекает из украинского политического кризиса и «крымского вопроса», что способствовало попытке изоляции России от основных внешнеторговых партнеров в Европе посредством введения антироссийских санкций. Азербайджан, в свою очередь, в условиях ограничения торговли со странами Евросоюза, нарастил долю продовольственных товаров и сельскохозяйственного сырья в импорте России, увеличив поставки фруктов, орехов и овощей, которые в структуре товарного импорта в 2018 г. превысили суммарно 65\%. [8]

Географически структуру импорта продовольственных товаров и сельскохозяйственного сырья условно можно разделить на три группы: страны Евросоюза, страны-партнеры на постсоветском пространстве и страны дальнего зарубежья (рисунок 2).

Импорт продовольственных товаров и сельскохозяйственного сырья более чем на 55\% приходится на страны дальнего зарубежья, но

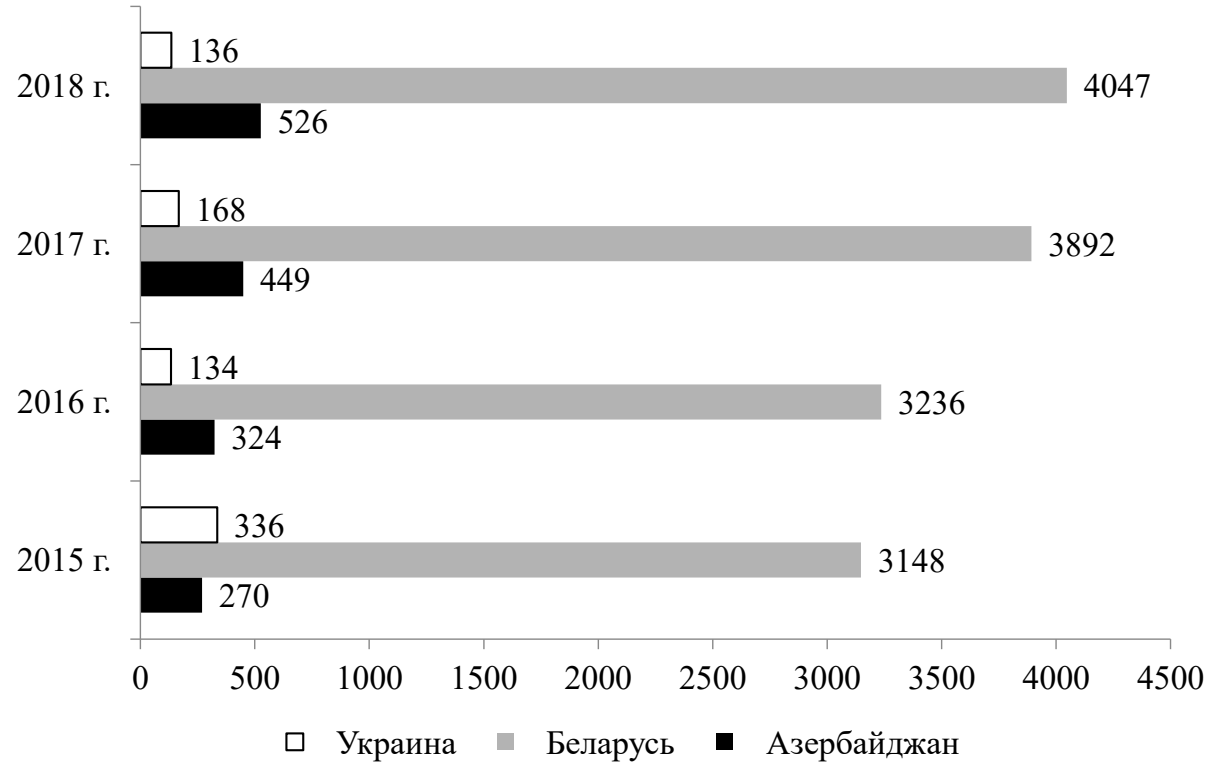

Рисунок 1. Импорт продовольственных товаров и сельскохозяйственного сырья из стран-партнеров на постсоветском пространстве, млн. долл. США Источник: рассчитано автором по данным Федеральной службы государственной статистики [7] 


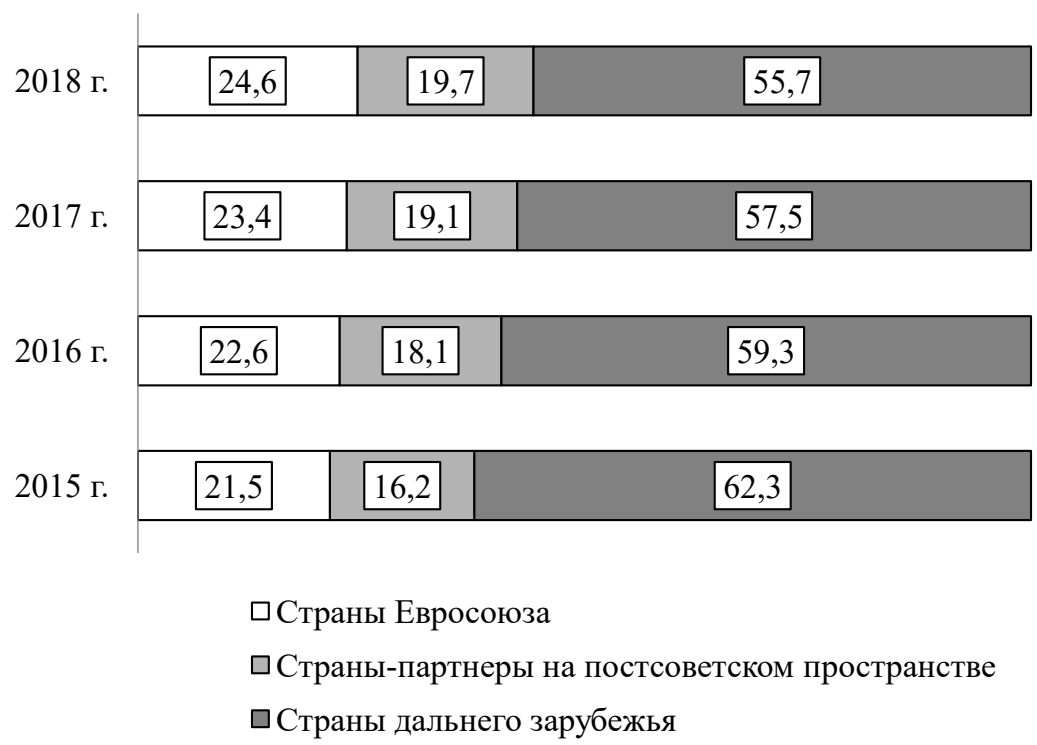

Рисунок 2. Структура импорта продовольственных товаров и сельскохозяйственного сырья, \% Источник: рассчитано автором по данным Федеральной службы государственной статистики [7]

в динамике сократился 6,6\%. Евросоюз на фоне санкций не только не уменьшил собственную долю в импорте продовольственных товаров и сельскохозяйственного сырья России, но даже нарастил, что на фоне роста объема абсолютного показателя свидетельствует о низкой эффективности российского эмбарго в адрес европейских стран. Рост доли стран-партеров на постсоветском пространстве в импорте России говорит об углублении внешнеторговых связей с ними, что происходит за счет усиления роли Беларуси.

Таким образом, развитие импорта продовольственных товаров и сельскохозяйственного сырья после введения антироссийских санкций, в ответ на которые было введено эмбарго, должным образом не сработало в сторону Евросоюза, укрепило положение России и Беларуси на российском рынке, и повлияло на сокращение доли стран дальнего зарубежья в импорте России.

Импорт продовольственных товаров, запрещенных к ввозу в Россию, географически изменился относительно 2015 г., поскольку из числа поставщиков рыбы живой, охлажденной и замороженной выбыли Норвегия, Гренландия, Исландия, Новая Зеландия, Индонезия, уступив место Фарерским островам (Дания). Из поставщиков молочной продукции Швейцария, Литва, Италия, Франция, чью нишу практически полностью заняла Беларусь. По ввозу всех видов мяса и плодов и овощей диверсификация сильно уменьшилась с разнообразного списка, где были представлены государства Евросоюза и
Юго-Восточной Азии, до узкого перечня странпартнеров на постсоветском пространстве (Беларусь, Азербайджан, реже Армения, Казахстан, Киргизия, Узбекистан), Латиноамериканских стран (Бразилия, Аргентина, Парагвай, Уругвай, Чили), Израиля, Ирана, Египта, Индии, Китая и стран Африки [7].

Импорт продовольственных товаров и сельскохозяйственного сырья в России изменился в положительную сторону после введения антироссийских санкций и ответных мер в виде продовольственного эмбарго. Как показал анализ объемов и структуры динамики импорта продовольственных товаров и сельскохозяйственного сырья по странам дальнего зарубежья, странампартнерам на постсоветском пространстве и Евросоюза, российское эмбарго оказалось неэффективным, поскольку объем и доля Евросоюза в российском импорте продовольственных товаров и сельскохозяйственного сырья в динамике выросла. Отрицательно сказались ограничительные меры на импортных поставках из стран дальнего зарубежья. Что касается странпартнеров на постсоветском пространстве, то отчасти они расширили свое собственное влияние на российском рынке, а с другой стороны, через них на российский рынок продолжают поступать продовольственные товары и сельскохозяйственное сырье из стран Евросоюза.

В свою очередь, российский АПК, неспособный в короткие сроки восполнить дефицит продовольственных товаров и сельскохозяй- 
ственного сырья на внутреннем рынке, имеет гораздо больше шансов на ускоренное развитие в условиях политики государственного протекционизма, что должно также сопровождаться ограничением в разумной степени поставок из Беларуси контрафактной продукции, заведомо по демпинговой цене, в отношении которых российские производители не могут конкурировать с белорусской продукцией по цене. Однако более важным направлением будет обеспечение вливания инвестиций непосредственно в агропроизводство для чего необходимо существенно смягчить фискальную и денежно-кредитную политику.

\section{Библиографический список}

1. Бредихина Ю.А. Основные результаты импортозамещения в АПК России // Закономерности развития региональных агропродовольственных систем. 2018. № 1. С. 27.

2. Малюк Л.И., Павлов А. Ю. Импортозамещение - стратегия развития России в условиях глобализации экономики // XXI век: итоги прошлого и проблемы настоящего плюс. 2015. Т. 3. № 6 (28). С. 370-374.

3. Алтухов А.И. Продовольственная безопасность России в условиях зарубежных санкций // АПК: Экономика, управление. 2014. № 12. С. 19-29.

4. Семыкин В.А., Пигорев И.Я., Зюкин Д.А. Обеспечение продовольственной безопасности России в условиях экономическо-политических санкций: успехи и проблемы // Азимут научных исследований: экономика и управление. 2019. Т. 8. № 3 (28). С. 336-339.

5. Иовлев Г.А. Импортозамещение на рынке сельскохозяйственной техники // Теория и практика мировой науки. 2017. № 9. С. 68-73.

6. Суханова И.Ф., Лявина М. Ю. Формирование экспортного продовольственного потенциала России и ее регионов в условиях импортозамещения // Аграрный научный журнал. 2017. № 1. С. 80-85.

7. Показатели, характеризующие импортозамещение в России. Федеральная служба государственной статистики. [Электронный ресурс]. Режим доступа: https://www.gks.ru/folder/11188 (Дата обращения: 29.01.2020 г.).

8. Внешняя торговля России. [Электронный ресурс]. Режим доступа: https://russian-trade.com/countries/ (Дата обращения: 29.01.2020 г.). 